\title{
Michel Serres - od komunikacijske družbe k učeči se družbi
}

\author{
Nadja Dobnik
}

\begin{abstract}
Michel Serres je v šestdesetih letih pisal o Zemlji kot o globalnem komunikacijskem prostoru. Danes kritično, vendar z optimizmom, razmišlja o možnostih, ki jih ponujajo računalniška omrežja $v$ zvezi z brezplačnim dostopom do znanja, s širjenjem znanja in nastajanjem novih središč, vse to pa nakazuje pot komunikacijske družbe $v$ učečo se družbo prihodnosti.
\end{abstract}

Francoskega humanista, matematika in filozofa Michela Serresa ni mogoče uvrstiti v nobeno smer moderne misli in filozofije. Njegov odnos do sveta je kritičen in brezkompromisen, vendar prežet $\mathrm{z}$ vedrino in optimizmom. Sam zase pravi, da je filozof lisjak, nenehno v gibanju, iskanju novih poti in odgovorov, nikoli vklenjen in podrejen. $\mathrm{V}$ ospredju njegovega razmišljanja sta nujnost sožitja med eksaktnimi vedami in humanistiko, vprašanje globalizacije problemov in s tem povezan odnos človeštva do Zemlje in sveta, predvsem pa pomen prostega dostopa do znanja za skupno prihodnost s prepletanjem kultur, ras in vednosti.

\section{Med mafematiko in filozofijo}

Michel Serres se je rodil leta $1930 \mathrm{v}$ francoskem mestu Agen. Najprej je študiral matematiko in jo absolviral, na Ecole normale supérieure pa je končal še študij filozofije. Po diplomi je predaval na univerzah v Clermont-Ferrandu in Vicennes in zgodovino znanosti na Sorboni, leta 1968 je doktoriral iz Leibniza. Od leta 1984 redno predava na Standfordu in Sorboni, leta 1990 pa je postal tudi član Francoske akademije znanosti.

Med njegovimi najpomembnejšimi deli je treba najprej omeniti pionirski spis Leibnizov sistem in njegovi matematični modeli iz leta 1968, ki je nekakšna arheologija moderne matematične vede.

$\mathrm{V}$ šestdesetih letih je začel nastajati niz petih del z naslovom Hermes. V njih je Serres jasno napovedal, da je paradigmo produkcije enkrat za vselej zamenjala paradigma komunikacije in da bog modernega sveta ni Prometej, bog proizvodnje, temveč Hermes, posrednik, bog komunikacije.

$\mathrm{V}$ osemdesetih letih je $\mathrm{v}$ delu Pet čutov kot filozof nastopil proti nemoči moderne misli, da bi izstopila iz besed in interpretacij, in opozoril na nujnost, da bi se filozofija vrnila k stvarem samim, k svetu, izgubljenem za jezikovnim zaslonom.

Leta 1990 je doživelo velik odmev delo Naravna pogodba, v katerem Serres poseže v razmerje med znanstveno ter pravno resnico in resno opozori na dejstvo, da vprašanja sodobnega sveta, ki ga obvladujeta znanost in tehnika, zahtevajo večjo medsebojno povezanost med pravom in znanostjo, zlasti pa nov premislek o odnosu človeka do narave. Predvsem je revolucionarna njegova zahteva, da mora Narava dobiti status pravnega subjekta, saj je nujno, da človeštvo začne obravnavati Zemljo kot celoto in jo razumeti kot enakovrednega partnerja. To pa pomeni, da Zemlja ni več globalen predmet kolektivne lastniške pravice človeštva,

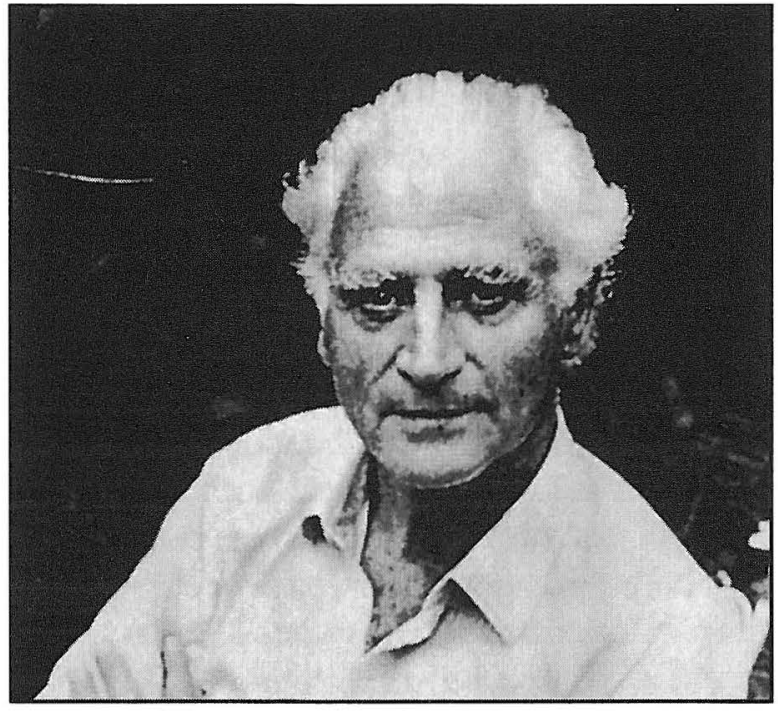

temveč sopodpisnik pogodbe o skupnem sožitju, ki mora temeljiti na pripoznanju enakomočja drugega.

$\mathrm{V}$ delu $\mathrm{z}$ naslovom Le tiers-instruit (kar bi lahko opisno prevedli kot novo vrsto človeka, ki se razvija s prepletanjem kultur, ras in vednosti) govori o pomenu prepletanja kultur in sposobnosti prilagajanja ter sprejemanja drugih kultur in ras pri vzgoji, izobraževanju ter pridobivanju znanja. Vsako izkustvo mora pripeljati do nove oblike mešanja in stapljanja. Ne gre več zgolj za prilagajanje in strpnost do drugačnega, temveč za lastno spreminjanje $\mathrm{z}$ mozaikom vtisov, izkustev in znanja, ki jih sprejemamo.

Atlas, delo, ki je izšlo 1994, je razmišljanje o vprašanjih, ki jih danes pred človeka postavlja nov atlas, globalen načrt sveta. Vse se nezadržno spreminja: znanost, njene metode in iznajdbe, način spreminjanja stvari, tehnika in z njo delo, njegova organizacija in socialno okolje, ki ga to oblikuje ali ruši, družina in šola, pisarne in tovarne, podeželje in mesta, narodi in politika, bivanjski prostor in potovanja, meje, bogastvo in beda, spočenjanje otrok in njihova vzgoja, vojskovanje in iztrebljanje, nasilje, pravo, smrt, praznovanja itd. Kje bomo živeli, se sprašuje Serres. S kom bomo živeli? S čim se bomo preživljali? Kam se bomo selili? Kaj moramo vedeti, kaj se moramo naučiti, kaj poučevati, početi? Kako se bomo torej vedli? Skratka, kako se bomo znašli v svetu, ki nastaja pred nami in za katerega se zdi, da spodriva starega, ki 
so ga jasno opredeljevali posamezni kraji in države. Prostor sam se spreminja in zahteva nove načrte sveta.

Delo Sporočila na daljavo je zapis predavanj, ki jih je imel Michel Serres leta 1995 v Kanadi. Naš odnos do resnice, meni Serres, je danes na globalni svetovni ravni primerljiv s statusom, ki ga je imela resnica v stari Grčiji: gledamo jo v luči malega zaslona, zasičenega s trupli, razdejanjem, vojnami, vsiljenimi podobami. S škatlo, ki je hkrati gledališče in svetišče, ustvarjamo male bogove. Vendar, kateri bogovi so pravi in kateri lažni? Po katerih merilih naj se zanje odločamo in koliko svobode pri presojanju še imamo? Le zavest o pripadnosti vsemu človeštvu in ponovno priznanje vednosti za naše oblikovanje in našo notranjo rast nam lahko pomagata razsojati med pravimi in lažnimi bogovi.

\section{Prometeja zamenja Hermes}

Serresovo razmišljanje o vlogi komunikacijskih sredstev in poti sega $v$ šestdeseta leta in ostaja $v$ ospredju vse do danes. Odnos do dela se je $\mathrm{z}$ informacijsko tehnologijo in možnostmi za komuniciranje bistveno spremenil in na mesto Prometeja, boga proizvodnje, transformacije, je stopil Hermes, bog posredovanja in komunikacije. Težišče človekove dejavnosti ni več v predelovanju in proizvajanju, temveč v prenašanju sporočil in posredovanju informacij. Globalizacija odnosov in komunikacij pa obenem pomeni tudi globalizacijo problemov in zato zahteva celovit pogled na svet ter usodo našega planeta. Kot sta po eni strani znanost in tehnologija povezala svet $\mathrm{v}$ celovito komunikacijsko mrežo, pa je po drugi strani naloga filozofije, da spregovori o globalnih problemih in razmišlja o globalnih rešitvah problemov, ki se pojavljajo v znanosti. Serres svoje sodobnike opozarja, da je svet tu in da nam grozi resna nevarnost, ker ga v svoji igri nikoli ne dojemamo kot resnega protagonista, in da se prav zato dogajajo katastrofe, kot sta Hirošima in ozonska luknja. Za takšno pozabo sveta ni odgovorna samo znanost, marveč sta odgovorna tudi pravo in filozofija.

Odkar je človeštvo $\mathrm{z}$ množičnimi občili povezano v celoto, mora osmisliti svoj obstoj v odnosu do Zemlje. Serres primerja Zemljo z ladjo, na katero je vkrcano človeštvo. Vsi ljudje smo med seboj usodno povezani in zavedati se moramo, da drugih ladij nimamo. Zato je skrajni čas, da se začnemo do Zemlje vesti odgovorno in spoštljivo.

\section{Nujno sožitje znanosti in humanistike}

Osrednje gibalo Serresovega razmišljanja je vprašanje razmerja med eksaktnimi vedami in filozofijo. Čeprav je najprej študiral matematiko in ostaja globoko zavezan načelom eksaktnega mišljenja, se je prenehal ukvarjati z znanostjo in se posvetil filozofiji. Sam zase pravi, da ga opredeljuje prav dvojnost izobrazbe, ki je znanstvena in humanistična. Od matematike je prevzel predvsem natančnost in strogost v sklepanju in izražanju, hitrost in dinamičnost razmišljanja. Obenem pa pripada generaciji, ki jo je zaznamovala Hirošima. Ob tem dogodku so ljudje prvič resno podvomili o znanosti kot o vsemogočni ustvarjalki dobrin. To je bila prva klofuta znanstveni narcisoidnosti in Serres se v svoji filozofiji nenehno vrača $\mathrm{k}$ vprašanju človekovega odnosa do sveta in narave, $v$ razmerju med znanostjo ter filozofijo in tudi $\mathrm{v}$ razmerju med pravom in znanostjo.

Razum lahko vse pojasni in interpretira. Znanost in tehnika navdušujeta $s$ hitrimi in učinkovitimi rešitvami, ne ukvarjata pa se z vprašanji človekovega notranjega ravnotežja, ki ga rušijo hitre spremembe $v$ okolju. Znanost in tehnika ne moreta razložiti trpljenja, bolečine, zla, stisk, zaradi katerih človeštvo od nekdaj trpi. Zgodovina človeštva je prežeta s trpljenjem ter $\mathrm{z}$ bolečino in nobena znanost ne more tega pojasniti.

Serres očita znanosti in filozofiji, da sta se zaprli vsaka v svoj svet, zato vidi eno temeljnih potreb našega časa v njuni spravi in v skupnem iskanju odgovorov na vprašanja prihodnosti in usode sveta. Dandanes prevladujejo na eni strani ljudje, ki so kultivirani, vendar neizobraženi, na drugi strani pa so znanstveniki, izobraženi in specializirani ljudje, ki so nevzgojeni, brez kulture in posluha za ljudi. Znanost in tehnika sta edini resni projekt, ki ga Zahod še priznava, in če bo imela moč odločanja le znanost, lahko $v$ takih razmerah ravna in ukrepa povsem neodgovorno.

Obenem pa je tudi filozofija izgubila kritičnost do sveta ter civilizacije in se pred spremembami v družbi, ki se je hipertehnizirala, že petdeset let zapira v svoj jezik in svet ukvarjanja s človeškimi odnosi. Kadar je filozofija kritična do tehnike, naredi to $s$ skrajno tehniziranimi postopki, kot da ne bi bilo okrog nje ničesar živega. Vsiliti poskuša svoj jezik in model medčloveških odnosov.

V sodobni filozofiji ni sveta, meni Serres, zato tudi ni pogleda nanj. So samo majhne prevare. Moderna filozofija govori o govorici in piše o pisavi. Toda obstajajo tudi predmeti, in ti se bodo prav kmalu zbudili. Bolj ko se zavedamo moči tehnike, bolj nemirni postajamo zaradi razvoja sveta $\mathrm{v}$ vsej njegovi celovitosti. Zemlja se korenito spreminja. Kako ovrednotiti te spremembe? Kako razmišljati o njih? V nasprotju z modernimi smermi filozofije, ki se že petdeset let ukvarjajo le s tropi, pisavo in pravilno postavljenimi stavki, pa poskuša Michel Serres tako govoriti o naravi, kot je danes o njej mogoče govoriti, globalno.

\section{Od komunikacijske družbe $\mathbf{k}$ družbi pedagogike}

V enem od zadnjih intervjujev Michel Serres razmišlja tudi o vlogi novih tehnologij v izobraževanju. Z globalizacijo komunikacij so nastala omrežja, ki omogočajo posredovanje informacij in znanja, nastajanje novih središč in virov znanja. Velik pomen računalniških omrežij, kot je Internet, vidi Serres predvsem v možnosti brezplačnega dostopa do znanja. Koncentriranje znanja tako kot koncentriranje denarja postavlja vprašanje lastništva. Ko bo znanje dovolj razširjeno in se bo skozi nova središča razširilo po omrežjih, se bo pojem lastništva izgubil in država si bo znanje vedno težje lastila. Demokratični smo bili v marsičem, samo v možnosti dostopa do znanja ne. $\mathrm{V}$ tem vidi Serres prehod družbe komunikacije v družbo pedagogike. Poudarja, da bodo odnosi med učiteljem in učencem bolj horizontalni, čustveni ter intenzivni.

$\mathrm{V}$ etimološkem pomenu je pedagogika potovanje otroka $\mathrm{k}$ viru znanja. Vse do danes so obstajala središča znanja, kot so šole, izobraževalni centri, knjižnice, univerze. Z novimi komunikacijskimi potmi je znanje tisto, ki potuje. Ta preobrat popolnoma spreminja predstavo o razredu ali učnem središču. Znanje se bo razpršilo po omrežjih, ki obenem omogočajo razširjanje znanja in nastajanje novih virov. Znanje bo vedno bolj prihajalo do ljudi brez posrednikov in vsak ga bo zajemal po svoje.

Dejstvo, da bodo v istem »razredu« ali skupini študentje iz različnih koncev sveta, pa ne izključuje prisotnosti profesorjev. Človek je tisti, ki poučuje, in pisana beseda ima drugačno sporočilno vrednost kot govor, žar gibov in mimike. Serres govori o profesorjih nomadih in poudarja, da se potovanjem profesorjev ne bo mogoče izogniti, čeprav se bo znanje razpršilo po prostoru. 
Tako kot znanje bodo po prostoru potovali tudi profesorji in ne bodo več priklenjeni na šole, učna središča in univerze.

$\mathrm{V}$ današnjem času, prežetem s hitenjem, hotenji, $\mathrm{z}$ nasiljem in s smrtjo, z negativnimi čustvi in s strahovi, ostaja optimizem Michela Serresa zgled za pokončno držo in neizčrpno vero v človeka: »Čeprav mi je bilo po družinski tradiciji usojeno pravzaprav fizično delo in me je mladost, ki jo je oblikovalo deset let vojne, zaznamovala $\mathrm{z}$ negativnimi občutji in razmišljanjem, sem se $\mathrm{v}$ obeh primerih znašel na drugem bregu; resnično imam rad le pozitivne vrednote, občutim neizmerno srečo, da opravljam poklic, ki sem si ga izbral: poučevanje - obožujem svoje študente - in pisanje knjig - tudi plačal bi za to, da bi to lahko počel, če bi bilo treba. Navdušenje nad filozofskim življenjem me ni nikoli zapustilo. Če bi hotel brez sramu izraziti, kakšen občutek me nenehno spremlja, ne bi niti za hip odlašal: radost, neizmerna, iskriva, sveta radost, da imam o čem razmišljati. Pogosto celo vedrina.«

Nadja Dobnik,

predavateljica francoskega poslovnega jezika na Ekonomski fakulteti v Ljubljani

\section{Izbrana bibliografija Michela Serresa:}

Le Système de Leibniz et ses modèles mathématiques, 2. knjigi, Presses universitaires, Pariz 1968

Hermès I. La communication, Editions de Minuit, Pariz 1969.

Hermès II. L'interférence, Editions de Minuit, Pariz 1972.

Hermès III. La traduction, Editions de Minuit, Pariz 1974.

Hermès IV. La distribution, Editions de Minuit, Pariz 1977.

Hermès V. Le passage du Nord-Ouest, Editions de Minuit, Pariz 1980.

Les Cinq Sens, Grasset, Pariz 1985.

Statues, Editions François Bourin, Pariz 1987.

Le contrat naturel, Editions François Bourin, Pariz 1990.

Le Tiers-Instruit, Editions François Bourin, Pariz 1991.

Eclaircissements, Editions François Bourin, Pariz 1992.

Atlas, Editions Julliard, Pariz 1994.

Les messages à distance, Les grandes conferences, Editions Fides, Montréal 1995.

\section{Ințervjuji:}

Prečenje vednosti, Časopis za kritiko znanosti, št. 154-120, XXI/1993, str. 115-139.

Vers la société de pédagogie, v: Le délire multimédia, Télérama hors-série, 1996, str. 28-29. 